\title{
OBSERVATIONS ON SPONGE-DWELLING COLONIES OF SYNALPHEUS (DECAPODA, ALPHEIDAE) OF SULAWESI, INDONESIA
}

\author{
BY
}

\author{
KARIN DIDDEREN ${ }^{1}$ ), CHARLES H. J. M. FRANSEN ${ }^{1,3}$ ) and NICOLE J. DE VOOGD ${ }^{1,2}$ ) \\ 1) National Museum of Natural History, P. O. Box 9517, NL-2300 RA Leiden, The Netherlands \\ ${ }^{2}$ ) Institute for Biodiversity and Ecosystem Dynamics (Zoological Museum), University of \\ Amsterdam, P.O. Box 94766, NL-1090 GT Amsterdam, The Netherlands
}

\begin{abstract}
In this study we recorded sponge-dwelling colonies of four Synalpheus species from several locations around the island of Sulawesi, Indonesia. We measured characteristics of the colony organization like colony size, sex ratio, within-colony morphological variation and size frequencies, and recorded the infection with abdominal and thoracic bopyrid isopod parasites. In one particular colony of Synalpheus neptunus neptunus, we found one large ovigerous female or 'queen' together with many male individuals, indicating a eusocial colony organization. A percentage of males in four of the five colonies of this species lack a rostrum. This morphological variation within the colony could be an indication of a highly developed social structure, where behavioural variety (e.g., labour division) is expected. Illustrated diagnoses and restricted synonymies of the species recorded are provided.
\end{abstract}

\section{RÉSUMÉ}

Dans cette étude ont été étudiées des colonies de quatre espèces de Synalpheus habitant des éponges de plusieurs sites autour l'ile de Sulawesi, Indonésie. Les caractéristiques de l'organisation de la colonie comme la taille de la colonie, le sex ratio, les variations morphologiques et les fréquences de taille à l'intérieur de la colonie ont été mesurées, et l'infection par des isopodes bopyridés parasites abdominaux ou thoraciques a été notée. Dans l'une de ces colonies de Synalpheus neptunus neptunus, une grande femelle ovigère ou "reine" a été trouvée parmi de nombreux individus mâles, indiquant une organisation de la colonie de type eu-social. Un certain pourcentage de mâles dans quatre des cinq colonies présentent une absence de rostre. Cette variation morphologique à l'intérieur de la colonie pourrait être une indication d'une structure sociale hautement développée, dans laquelle des comportements différents (p.e. division du travail) sont à attendre. Des diagnoses illustrées et des synonymies réduites sont données pour quatre espèces.

\footnotetext{
3) Author for correspondence; e-mail: fransen@ @aturalis.nnm.nl

(C) Koninklijke Brill NV, Leiden, 2006

Crustaceana 79 (8): 961-975 


\section{INTRODUCTION}

The snapping shrimp genus, Synalpheus Bate, 1888 (Decapoda, Alpheidae), with over 100 species described, comprises one of the largest genera of marine decapod crustaceans in shallow tropical waters (Banner \& Banner, 1975). Most are commensal associates of sessile marine invertebrates, including corals, sea anemones, sea urchins, and particularly sponges and crinoids (Bruce, 1976; VandenSpiegel et al., 1998; Duffy \& Macdonald, 1999). Alpheids, among the most abundant mobile cryptofauna on tropical reefs (Bruce, 1976; Duffy, 1996b), produce a crackling sound by the snapping of their chelae (Johnson et al., 1947; Duffy, 1992) familiar to SCUBA divers in the tropics. Sponge-dwelling species of Synalpheus are often found in large groups within a sponge (Pearse, 1950). Skewed sex ratios within these groups have demanded explanations for years. Recently, genetic data showed that colony members of Caribbean Synalpheus species are closely related (Duffy, 1996a; Duffy et al., 2002). Interestingly, these colonies are found eusocial (Duffy \& Macdonald, 1999) in accordance with conventional criteria, used to describe insect groups.

Eusociality is the most extreme form of animal social organization characterized by three features: overlapping generations, reproductive division of labour, and cooperative broodcare (Andersson, 1984). Eusociality is well-known among social insects and the African mole-rats (Jarvis, 1981), but the first eusocial marine animal, a sponge-dwelling alpheid shrimp of the genus Synalpheus, was only recently recognized (Duffy, 1996a). Colonies of the Caribbean Synalpheus regalis Duffy, 1996 comprise up to 350 individuals inside a sponge, invariably with only one reproductive female. The larger colony members defend the colony against heterospecific intruders (Duffy, 1996a). It is now known that several species of sponge-dwelling alpheid shrimps (Synalpheus) exhibit monogynous, eusocial colony organizations, yet there are no descriptions of colonial organizations of Synalpheus species outside the western Atlantic. In this study, colonies of Synalpheus species from several locations around the island of Sulawesi, Indonesia, in the Indo-West Pacific, are recorded with observations on withincolony morphological variety. Furthermore, the data obtained on these spongedwelling shrimp were used to describe the social structure and host-use patterns of Synalpheus species from this area, that are likely to have a colonial organization.

\section{MATERIAL AND METHODS}

Samples were collected using SCUBA at three sites on Sulawesi from July to October 2000 and from May till August 2002: (1) Bunaken Marine National Park, north Sulawesi (Alung Banua, SW Bunaken Island $\left(01^{\circ} 37.084^{\prime} \mathrm{N}\right.$ 
$\left.124^{\circ} 45.501^{\prime} \mathrm{E}\right)$ and $\mathrm{SW}$ Siladen Island $\left.\left(01^{\circ} 37.603^{\prime} \mathrm{N} 124^{\circ} 47.989^{\prime} \mathrm{E}\right)\right)$; (2) the Spermonde Archipelago, southwest Sulawesi (NW of Samalona island $\left(05^{\circ} 07^{\prime} 19.6^{\prime \prime} \mathrm{S}\right.$ $\left.119^{\circ} 20^{\prime} 24.6^{\prime \prime} \mathrm{E}\right)$; Kudingareng Keke $\left(05^{\circ} 06^{\prime} 11.7^{\prime \prime} \mathrm{S} 119^{\circ} 17^{\prime} 04.9^{\prime \prime} \mathrm{E}\right)$; Bone Lola

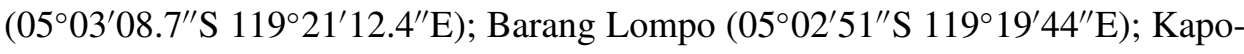
posang $\left(04^{\circ} 41.651^{\prime} \mathrm{S} 118^{\circ} 55.208^{\prime} \mathrm{E}\right)$; (3), Tanjung Bira, south Sulawesi (SW of Island Liukan, $05^{\circ} 38^{\prime} 16.6^{\prime \prime} \mathrm{S} 120^{\circ} 27^{\prime} 00.8^{\prime \prime} \mathrm{E}$ ).

Sponges were methodically sampled. Prior to collection, sponges were photographed under water and colour, lifeform, and depth were recorded. In the laboratory, the sponges were dissected to remove all associated animals. Sponge samples were identified and deposited at the National Museum of Natural History, Leiden and the Zoological Museum of Amsterdam. Shrimps were preserved in $70 \%$ ethanol, identified, measured, and sexed (ovigerous female, non-ovigerous female, normal male/juvenile, or morphologically different male/juvenile [males cannot be distinguished from juveniles, because they do not develop secondary sexual characteristics: see Felder, 1982]). The infection by bopyrid isopods was recorded.

The shrimp specimens examined are deposited at the Nationaal Natuurhistorisch Museum (previously Rijksmuseum van Natuurlijke Historie (RMNH)) at Leiden. The postorbital carapace length (pocl.) is used as a standard measurement indicating the size of the specimens.

\section{RESULTS}

Approximately 400 sponge specimens were collected, 17 of which contained more than 10 specimens of a single Synalpheus species. The Synalpheus (sub)species that were present in such large numbers were: S. fossor (Paulson, 1875), S. hastilicrassus Coutière, 1905, S. neptunus neptunus (Dana, 1852), and S. aff. neomeris (table I).

Three colonies of Synalpheus fossor were found in the sponge host, Mycale vansoesti Calcinai, Bavestrello, Totti, Romagnoli \& Cerrano, 2006 and one colony in Dysidea arenaria (Bergquist, 1961). Colony size varied between 13 and 20 specimens, and the individuals were skewed toward a larger size and also show a reproductive skew (fig. 1A). Both sexes have a normally developed major chela.

Synalpheus hastilicrassus was found in the sponges Fascaplysinopsis reticulata (Hentschel, 1912) and Dysidea arenaria. The colonies show a reproductive skew but no skew toward larger size (fig. 1B). In addition, two sponges with less than ten shrimps were found. Both sexes have a normally developed major chela.

Synalpheus neptunus neptunus was found in Coscinoderma aff. matthewsi Lendenfeld, 1886, Axynissa aff. cavernosa (Dendy, 1922), and Ircinia. The colonies 
TABLE I

Population characteristics of Synalpheus colonies, sponge host, and collection localites. Sponge hosts: Ac, Axinyssa aff. cavernosa (Dendy, 1922); Cb, Clathria basilana Levi, 1961; Cm, Coscinoderma aff. matthewsi Lendenfeld, 1886; Da, Dysidea arenaria (Bergquist, 1961); Fr, Fascaplysinopsis reticulata (Hentschel, 1912); Ge, Gelliodes sp.; Ir, Ircinia sp.; Mv, Mycale vansoesti Calcinai, Bavestrello, Totti, Romagnoli \& Cerrano, 2006. Locality: NS, North Sulawesi; SA, Spermonde Archipelago; SS, South Sulawesi. Colony size, sex ratio; fov., ovigerous females; males/juv., number of normal males or juveniles; abb. males, number of morphologically different males; female + bopyrid, the number of females infected by bopyrid isopods

\begin{tabular}{|c|c|c|c|c|c|c|c|}
\hline \multirow[t]{2}{*}{ Species of Synalpheus } & \multirow{2}{*}{$\begin{array}{c}\text { Sponge } \\
\text { host }\end{array}$} & \multirow{2}{*}{$\begin{array}{l}\text { Location } \\
\text { code }\end{array}$} & \multirow{2}{*}{$\begin{array}{l}\text { Colony } \\
\text { size }\end{array}$} & \multicolumn{4}{|c|}{ Numbers of: } \\
\hline & & & & fov. & $\begin{array}{l}\text { males/ } \\
\text { juv. }\end{array}$ & $\begin{array}{l}\text { abb. } \\
\text { males }\end{array}$ & $\begin{array}{r}\text { female }+ \\
\text { bopyrid }\end{array}$ \\
\hline \multirow[t]{4}{*}{ S. fossor (Paulson, 1875) } & $\mathrm{Da}$ & SS & 14 & 0 & 14 & 0 & 0 \\
\hline & $\mathrm{Mv}$ & NS & 20 & 3 & 17 & 0 & 0 \\
\hline & $\mathrm{Mv}$ & NS & 13 & 3 & 10 & 0 & 0 \\
\hline & $\mathrm{Mv}$ & SS & 18 & 1 & 17 & 0 & 0 \\
\hline \multirow[t]{2}{*}{ S. hastilicrassus Coutière, 1905} & Fr & NS & 20 & 4 & 16 & 0 & 0 \\
\hline & $\mathrm{Da}$ & SS & 10 & 2 & 8 & 0 & 0 \\
\hline \multirow[t]{5}{*}{ S.n. neptunus (Dana, 1852) } & $\mathrm{Ir}$ & SA & 32 & 0 & 27 & 5 & 0 \\
\hline & $\mathrm{Cm}$ & SA & 289 & 1 & 250 & 35 & 3 \\
\hline & Ac & SA & 42 & 0 & 41 & 0 & 1 \\
\hline & $\mathrm{Ac}$ & SA & 106 & 0 & 103 & 3 & 0 \\
\hline & $\mathrm{Cm}$ & SA & 388 & 0 & 372 & 16 & 0 \\
\hline \multirow[t]{6}{*}{ S. aff. neomeris (De Man, 1897) } & $\mathrm{Ge}$ & SA & 10 & 1 & 9 & 0 & 0 \\
\hline & $\mathrm{Cb}$ & SA & 78 & 11 & 67 & 0 & 0 \\
\hline & $\mathrm{Cb}$ & SA & 39 & 1 & 38 & 0 & 0 \\
\hline & $\mathrm{Cb}$ & SA & 29 & 4 & 25 & 0 & 0 \\
\hline & $\mathrm{Cb}$ & SA & 15 & 1 & 14 & 0 & 0 \\
\hline & $\mathrm{Cb}$ & SA & 15 & 1 & 14 & 0 & 0 \\
\hline
\end{tabular}

of S. neptunus neptunus are characterized by extremely large numbers. In only one colony, however, an extreme large, ovigerous female of $5.5 \mathrm{~mm}$ carapace length was found (fig. 5B). This female is morphologically different from the males in having the massive major chela of the first pereiopod replaced with a small chela, identical to the normal minor first chela, as has been observed in Synalpheus filidigitus Armstrong, 1949 by Duffy \& Macdonald (1999). The largest males reach a carapace length of $4.3 \mathrm{~mm}$. In four out of the five colonies collected, a certain percentage of the male specimens was observed to lack the rostrum (fig. 5D). Three non-ovigerous females possessing a well-developed major first chela, carry an abdominal bopyrid. These females are of the same size as the largest males (fig. 1C). Nine specimens with a lateral bopyrid under the carapace are all relatively small males. The colonies have a higher number of males in the larger size classes (fig. 1C). 

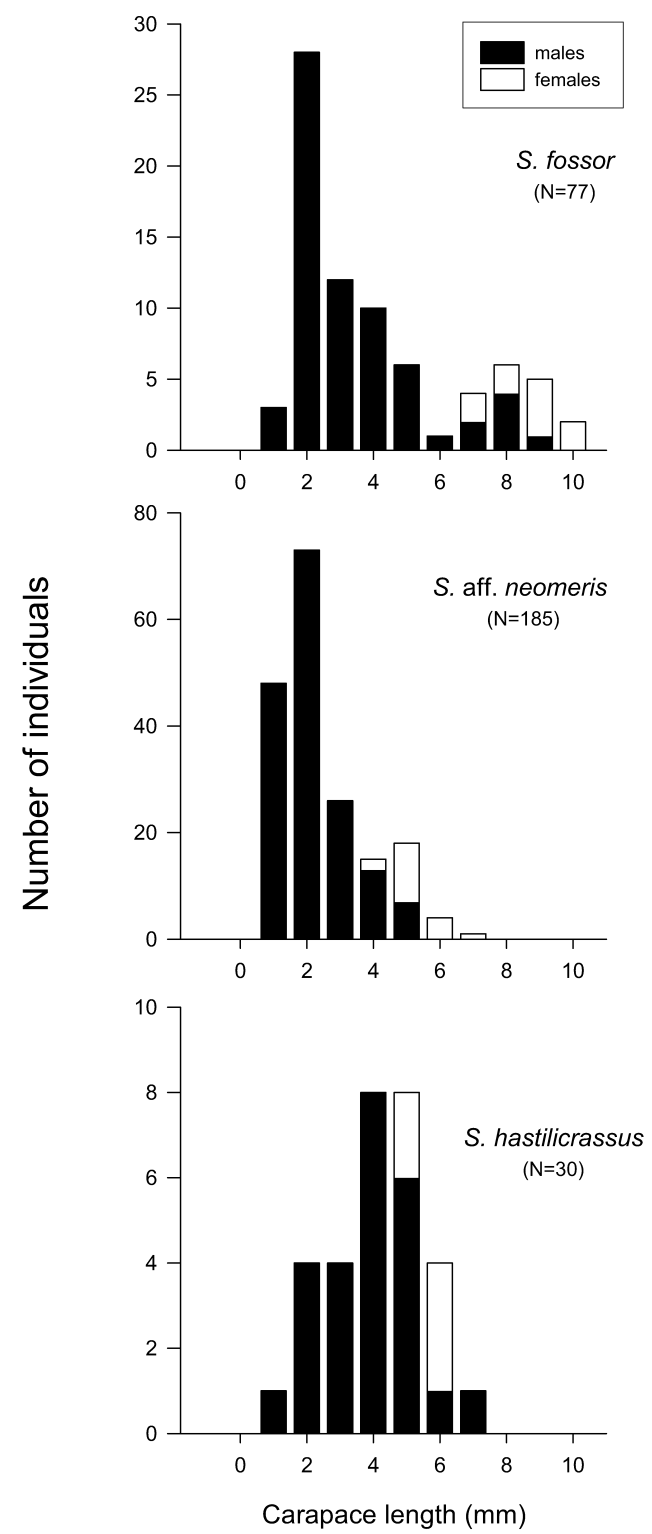

Fig. 1. Frequency distribution of carapace lengths of: A, 4 colonies of at least 10 individuals of Synalpheus fossor (Paulson, 1875); B, 2 colonies of at least 10 individuals of Synalpheus hastilicrassus Coutière, 1905; C, one colony of Synalpheus neptunus neptunus (Dana, 1852).

The six colonies of Synalpheus aff. neomeris with ten or more individuals were found in one specimen of an undescribed Gelliodes sp. and five specimens of Clathria basilana Levi, 1961. Colony size varied between 10 and 78 specimens, and individuals were skewed towards a larger size and also showed a reproductive 


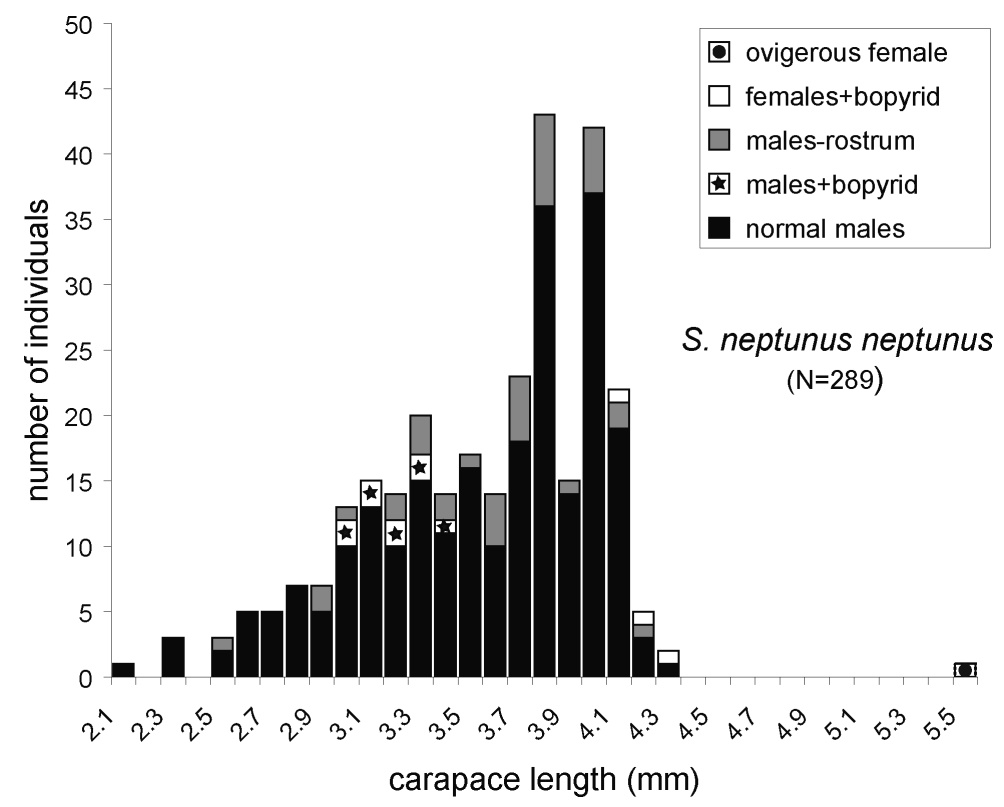

Fig. 2. Frequency distribution of carapace lengths of 6 colonies of at least 10 individuals of Synalpheus aff. neomeris (De Man, 1897).

skew (fig. 2). In addition, twenty-two sponges with less than ten shrimp specimens of this species were found. Both sexes have a normally developed major chela. A large number of sponge hosts contained other inhabitants, besides Synalpheus.

\title{
SYSTEMATIC ACCOUNT
}

\section{Synalpheus fossor (Paulson, 1875)}

\author{
(fig. 3A-D)
}

Alpheus fossor Paulson, 1875: 103, pl. 13 fig. 5 (type locality: Red Sea). Synalpheus fossor - Coutière, 1905: 872, pl. 70, fig. 6.

Synalpheus fossor var. propinqua De Man, 1909: 121; 1911: 250, pl. 9, fig. 39.

Synalphues trionyx Coutière, 1908: 196; 1921: 416, pl. 61, fig. 9.

Synalpheus Bakeri Coutière, 1908: 199.

Synalpheus Bakeri var. Stormi De Man, 1911: 253, pl. 9, fig. 40.

Material examined. - 14 specimens, RMNH D 51603: South Sulawesi, Tanjung Bira, Pulau Liukan, $5^{\circ} 38.227^{\prime} \mathrm{S} 120^{\circ} 27.013^{\prime} \mathrm{E}$; 5.vii.2002; $27 \mathrm{~m}$ depth; in Dysidea arenaria; collected by K. Didderen, KD/BI/050702/119. — 20 specimens, RMNH D 51604: North Sulawesi, SW Siladen Island, $1^{\circ} 37.603^{\prime} \mathrm{N} 124^{\circ} 47.989^{\prime} \mathrm{E}$; 17.v.2002; $15 \mathrm{~m}$ depth; in Mycale vansoesti; collected by K. Didderen, KD/MD11/170502/055. - 13 specimens, RMNH D 51505: North Sulawesi, SW Siladen Island, $1^{\circ} 37.603^{\prime} \mathrm{N} 124^{\circ} 47.989^{\prime} \mathrm{E} ; 23 . v .2002 ; 17 \mathrm{~m}$ depth; in Mycale vansoesti; collected by K. Didderen, KD/MD11/230502/083. - 18 specimens, RMNH D 51606; South Sulawesi, Tanjung Bira, Pulau Liukan, $5^{\circ} 38.227^{\prime} \mathrm{S} 120^{\circ} 27.013^{\prime} \mathrm{E} ; 5 . v i i .2002 ; 28 \mathrm{~m}$ depth; in Mycale vansoesti; collected by K. Didderen, KD/BI/050702/115. 
Diagnosis. - Rostrum distally acute, slightly longer than orbital teeth, reaching halfway to distal margin of basal segment of antennular peduncle. Orbital teeth distally acute, median margin proximally straight or concave. Stylocerite reaching just beyond distal margin of basal segment of antennular peduncle. Basicerite with acute superior spine reaching halfway basal segment of antennular peduncle, inferior spine as long as stylocerite. Carpocerite slightly longer than antennular peduncle. Scaphocerite reaching with distolateral tooth almost to or just beyond third segment of antennular peduncle, lamina narrow, reaching distal margin of second segment of antennular peduncle.

Chela of minor first pereiopod non-spatulate, fingers $2 / 3$ of palm length; merus with dorsodistal margin with acute tooth. Major chela with blunt tooth above dactylar articulation.

Third pereiopod without meral spines; one distoventral spine on carpus; propodus with row of c. 7-11 ventral spines, increasing in number with body size, and two ventrodistal spines; dactylus triunguiculate, moderately slender; unguis almost

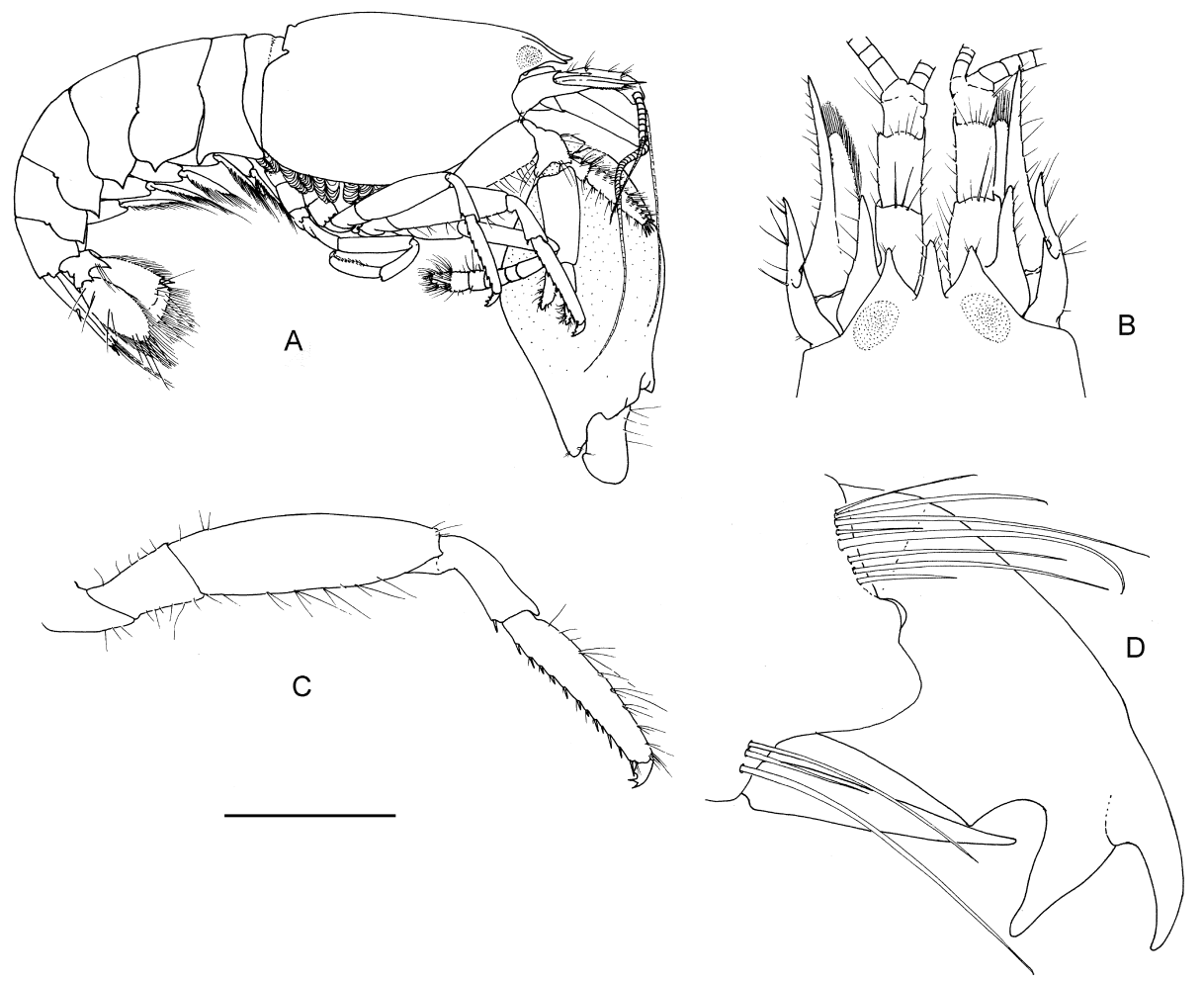

Fig. 3. Synalpheus fossor (Paulson, 1875). Male, pocl. 7.5 mm, RMNH D 51604. A, lateral aspect; $\mathrm{B}$, anterior appendages, dorsal aspect; $\mathrm{C}$, left third pereiopod; D, do., dactylus. Scale bar: $\mathrm{A}=4 \mathrm{~mm}$; $\mathrm{B}, \mathrm{C}=2 \mathrm{~mm} ; \mathrm{D}=0.15 \mathrm{~mm}$. 
as long as accessory tooth, proximally as broad as accessory tooth; corpus with angular tooth in distal third.

Telson with stout dorsal spines at about 0.5 and 0.7 of its length; distolateral angles slightly projecting, acute, 0.5-1.0 times length of outer posterior spine.

\title{
Synalpheus hastilicrassus Coutière, 1905
}

\author{
(fig. 4A-D)
}

Synalpheus hastilicrassus Coutière, 1905: 875, pl. 72, fig. 12 (type locality: Maldives).

Synalpheus hastilicrassus var. acanthitelsoniformis De Man, 1920: 108; 1922: 29, pl. 3 fig. 14-14a.

Material examined. - 20 specimens, RMNH D 51607: North Sulawesi, SW Bunaken Island, Alung Banua, $1^{\circ} 37.084^{\prime} \mathrm{N} 124^{\circ} 45.501^{\prime} \mathrm{E} ; 15 . \mathrm{v} .2002 ; 17 \mathrm{~m}$ depth; in Fascaplysinopsis reticulata; collected by K. Didderen, KD/MD7/150502/035. - 10 specimens, RMNH D 51608: South Sulawesi, Tanjung Bira, Pulau Liukan, $5^{\circ} 38.227^{\prime} \mathrm{S} 120^{\circ} 27.013^{\prime} \mathrm{E} ; 5$.vii.2002; $27 \mathrm{~m}$ depth; in Dysidea arenaria; collected by K. Didderen, KD/BI/050702/119.

Diagnosis. - Rostrum distally acute, slightly longer than orbital teeth, almost reaching distal margin of basal segment of antennular peduncle. Orbital hoods
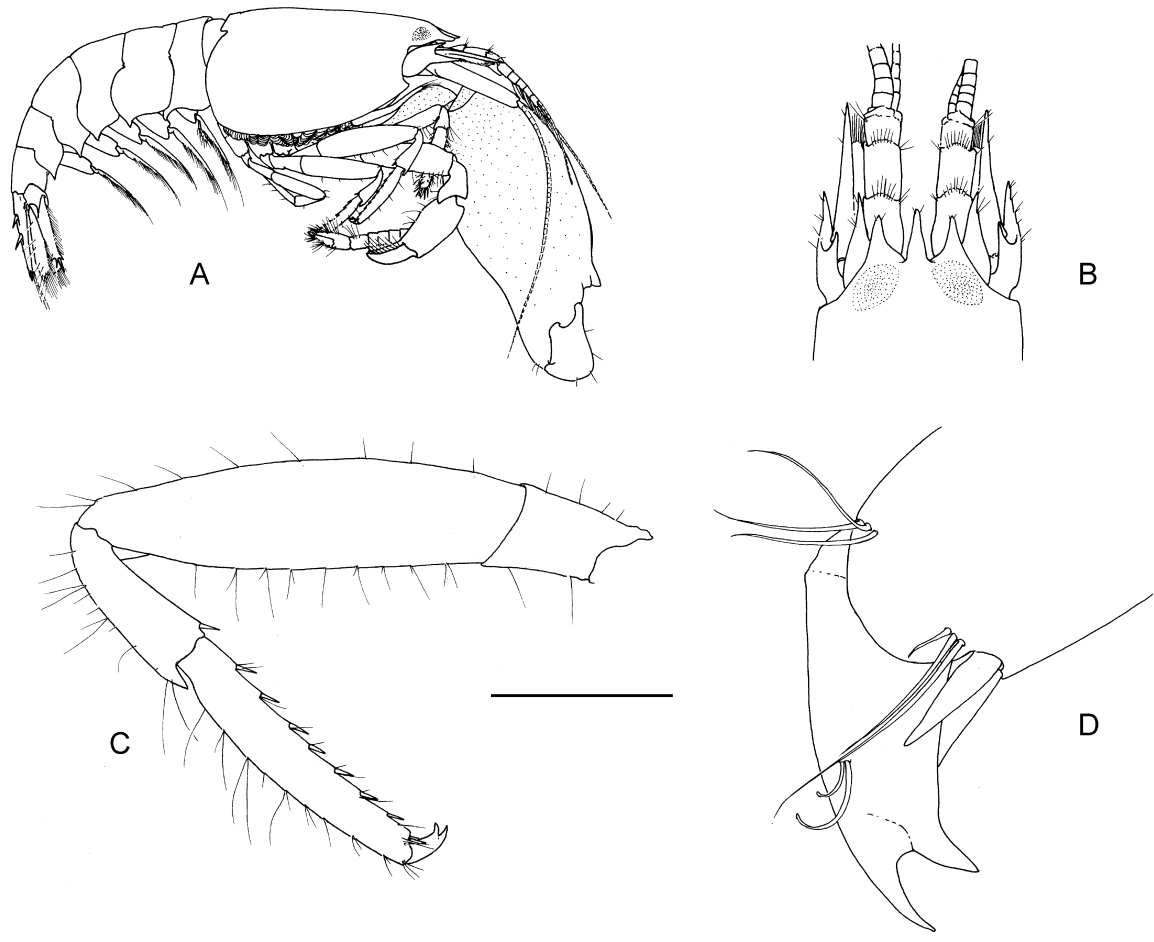

Fig. 4. Synalpheus hastilicrassus Coutière, 1905. Male, pocl. 5.6 mm, RMNH D 51608. A, lateral aspect; $\mathrm{B}$, anterior appendages, dorsal aspect; $\mathrm{C}$, left third pereiopod; D, do., dactylus. Scale bar: $\mathrm{A}=4 \mathrm{~mm} ; \mathrm{B}=2 \mathrm{~mm} ; \mathrm{C} 1=\mathrm{mm} ; \mathrm{D}=0.15 \mathrm{~mm}$. 
distally acute, median margin proximally straight. Stylocerite reaching to distal margin of basal segment of antennular peduncle. Basicerite with acute superior spine reaching halfway basal segment of antennular peduncle, inferior spine slightly longer than stylocerite. Carpocerite 1.5 times as long as antennular peduncle. Scaphocerite reaching with distolateral tooth just beyond third segment of antennular peduncle, lamina narrow, reaching distal margin of second segment of antennular peduncle.

Chela of minor first pereiopod spatulate, fingers $2 / 3$ of palm length; merus with dorsodistal margin without acute tooth. Major chela with blunt tooth above dactylar articulation.

Third pereiopod without meral spines; one distoventral spine on carpus; propodus with row of c. 8 ventral spines, increasing in number with body size, and two ventrodistal spines; dactylus biunguiculate, moderately slender; unguis as long as accessory tooth, proximally as broad as accessory tooth.

Telson with stout dorsal spines at 0.3 and 0.6 of its length; distolateral angles slightly projecting, acute, about one-third of length of outer posterior spine.

Synalpheus neptunus neptunus (Dana, 1852)

$$
\text { (fig. 5A-F) }
$$

Alpheus neptunus Dana, 1852a: 22; 1852b: 553, (1855) pl. 35, fig. 5 (type locality: Sulu Sea, Philippines).

Synalpheus neptunus - Coutière, 1898: 274.

Synalpheus neptunus neptunus - D.M. Banner \& A.H. Banner, 1975: 317, fig. 11.

Synalpheus theano (not De Man) - A.H. Banner \& D.M. Banner, 1966: 69, fig. 24.

Material examined. - 32 specimens, RMNH D 51609: South Sulawesi, Makassar, Samalona $\mathrm{NW}, 5^{\circ} 7.326^{\prime} \mathrm{S} 119^{\circ} 20.410^{\prime} \mathrm{E}$; 10.vi.2002; $16 \mathrm{~m}$ depth; in Ircinia sp.; collected by K. Didderen, KD/UP/100602/102. - 289 specimens, RMNH D 51610: South Sulawesi, Makassar, NW Samalona, $5^{\circ} 7.326^{\prime} \mathrm{S} 119^{\circ} 20.410^{\prime} \mathrm{E}$; 10.vi.2002; $16 \mathrm{~m}$ depth; in Coscinoderma aff. matthewsi; collected by K. Didderen, KD/UP/100602/103. - 42 specimens, RMNH D 51611: South Sulawesi, Makassar, Bone Lola, $5^{\circ} 3.145^{\prime} \mathrm{S} 119^{\circ} 21.207^{\prime} \mathrm{E} ; 12 . v i .2002 ; 14 \mathrm{~m}$ depth; in Axynissa aff. cavernosa, 049/061; collected by K. Didderen, KD/UP/120602/109. - 106 specimens, RMNH D 51612: South Sulawesi, Makassar, Bone Lola, $5^{\circ} 3.145^{\prime} \mathrm{S} 119^{\circ} 21.207^{\prime} \mathrm{E}$; $13 \mathrm{~m}$ depth; in Axynissa aff. cavernosa; collected by K. Didderen, KD/UP/170602/111 — 388 specimens, RMNH D 51613: South Sulawesi, Makassar, Bone Lola, $5^{\circ} 3.145^{\prime} \mathrm{S} 119^{\circ} 21.207^{\prime} \mathrm{E} ; 13 \mathrm{~m}$ depth; in Coscinoderma aff. matthewsi; collected by K. Didderen, KD/UP/170602/112.

Diagnosis. - Rostrum distally blunt, slightly longer than orbital teeth, reaching halfway to distal margin of basal segment of antennular peduncle. Orbital hoods distally rounded, median margin proximally concave. Stylocerite not reaching to distal margin of basal segment of antennular peduncle. Basicerite with small superior spine, inferior spine slightly longer than stylocerite. Carpocerite slightly longer than antennular peduncle. Scaphocerite reaching with distolateral tooth just 

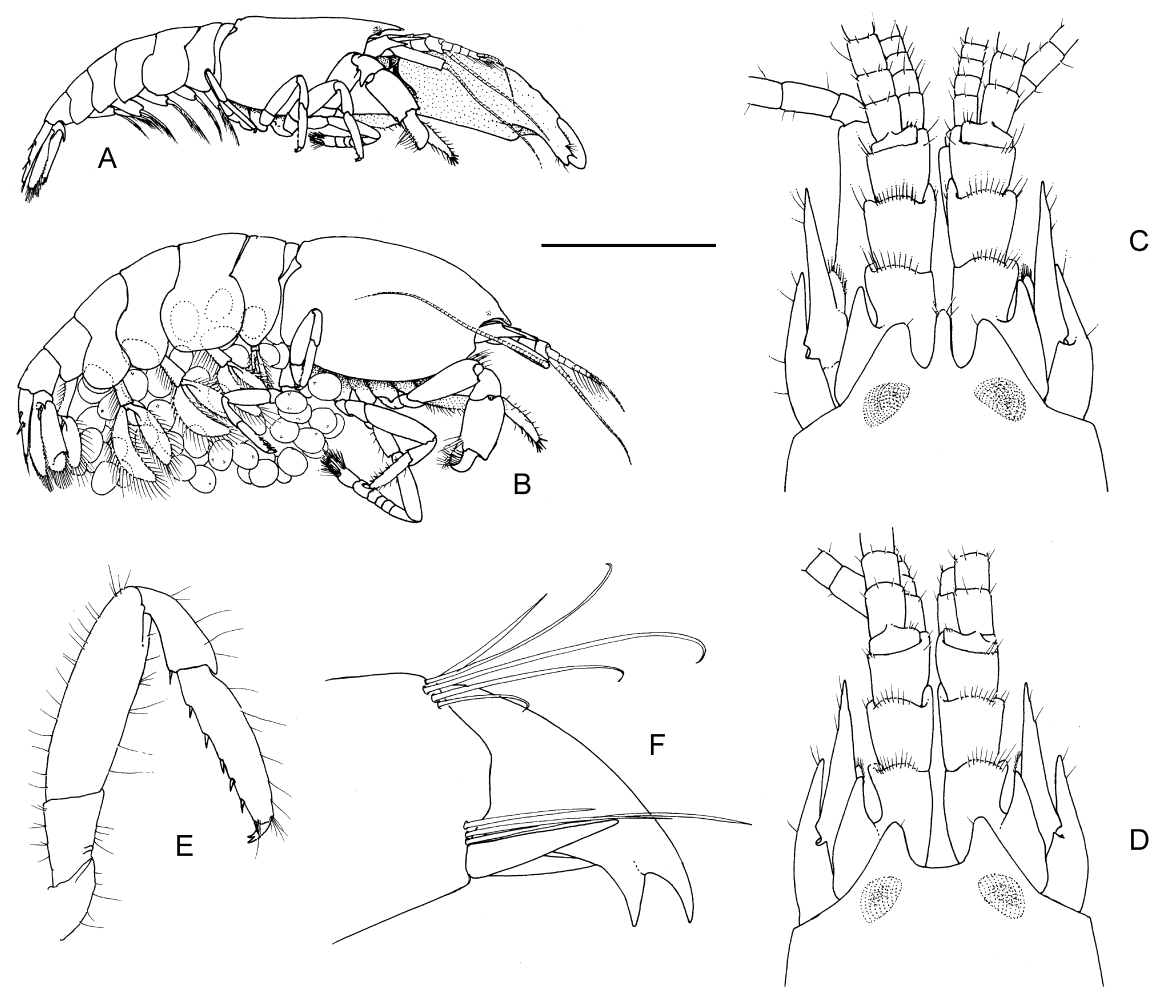

Fig. 5. Synalpheus neptunus neptunus (Dana, 1852). A, C, E, F, male, pocl. $4.2 \mathrm{~mm}$; B, ovigerous female, pocl. $5.5 \mathrm{~mm}$; D, aberrant male, pocl. $4.0 \mathrm{~mm}$, RMNH D 51610. A, B, lateral aspect; C, D, anterior appendages, dorsal aspect; E, left third pereiopod; F, do., dactylus. Scale bar: A, B = 4 mm; $\mathrm{C}, \mathrm{D}=2 \mathrm{~mm} ; \mathrm{E}=1.5 \mathrm{~mm} ; \mathrm{F}=0.15 \mathrm{~mm}$.

beyond second segment of antennular peduncle, lamina narrow, reaching distal margin of basal segment of antennular peduncle.

Chela of minor first pereiopod spatulate, fingers $2 / 3$ of palm length; merus with dorsodistal margin without acute tooth. Major chela with blunt tooth above dactylar articulation. Major chela not developed in females, both first pereiopods with morphology of minor chela of male.

Third pereiopod without meral spines; one distoventral spine on carpus; propodus with row of 5 ventral spines, and two ventrodistal spines; dactylus biunguiculate, moderately slender; unguis as long as accessory tooth, proximally as broad as accessory tooth.

Telson with stout dorsal spines at 0.33 and 0.66 of its length; distolateral angles not projecting, acute. 


\title{
Synalpheus aff. neomeris (De Man, 1897)
}

\author{
(fig. 6A-D)
}

Material examined. - 10 specimens, RMNH D 51614: South Sulawesi, Makassar, Bone Lola, $5^{\circ} 3.145^{\prime} \mathrm{S} 119^{\circ} 21.207^{\prime} \mathrm{E} ; 12 . v i .2002 ; 14 \mathrm{~m}$ depth; in Gelliode sp., collected by K. Didderen, KD/UP/120602/108. — 78 specimens, RMNH D 51615: South Sulawesi, Makassar, Kudingareng Keke; 29.viii.2000; 20 m depth; in Clathria basilana, collected by A. Janssen, Cb10/290800/KK/AJ. - 39 specimens, RMNH D 51616: South Sulawesi, Makassar, Barang Lompo, $05^{\circ} 02^{\prime} 51^{\prime \prime} \mathrm{S}$ $119^{\circ} 19^{\prime} 44^{\prime \prime} \mathrm{E}$; 26.viii.2000; $14 \mathrm{~m}$ depth; in Clathria basilana, collected by A. Janssen, Cb07/260800/ BL/AJ. - 29 specimens, RMNH D 51617: South Sulawesi, Makassar, Barang Lompo, $05^{\circ} 02^{\prime} 51^{\prime \prime} \mathrm{S}$ $119^{\circ} 19^{\prime} 44^{\prime \prime} \mathrm{E}$; 5.viii.2000; $13 \mathrm{~m}$ depth; in Clathria basilana, collected by A. Janssen, Cb01/050800/ BL/AJ. - 15 specimens, RMNH D 51618: South Sulawesi, Makassar, Barang Lompo, S05 $02^{\prime} 51^{\prime \prime} \mathrm{S}$ $119^{\circ} 19^{\prime} 44^{\prime \prime} \mathrm{E}$; 26.viii.2000; $10 \mathrm{~m}$ depth; in Clathria basilana, collected by A. Janssen Cb09/260800/ BL/AJ. - 15 specimens, RMNH D 51619: South Sulawesi, Makassar, Barang Lompo, S05 $02^{\prime} 51^{\prime \prime} \mathrm{S}$ $119^{\circ} 19^{\prime} 44^{\prime \prime}$ E; 20.ix.2000; 13 m depth; in Clathria basilana, collected by A. Janssen, Cb24/200900/ BA/AJ.

Diagnosis. - Rostrum distally blunt, slightly longer than orbital teeth, reaching distal margin of basal segment of antennular peduncle. Orbital hoods distally acute, median margin proximally convex. Stylocerite reaching to proximal third of second segment of antennular peduncle. Basicerite with distinct acute superior spine, inferior spine as long as stylocerite. Carpocerite longer than antennular peduncle. Scaphocerite reaching with distolateral tooth beyond antennular peduncle, lamina narrow, reaching or overreaching distal margin of ultimate segment of antennular peduncle.

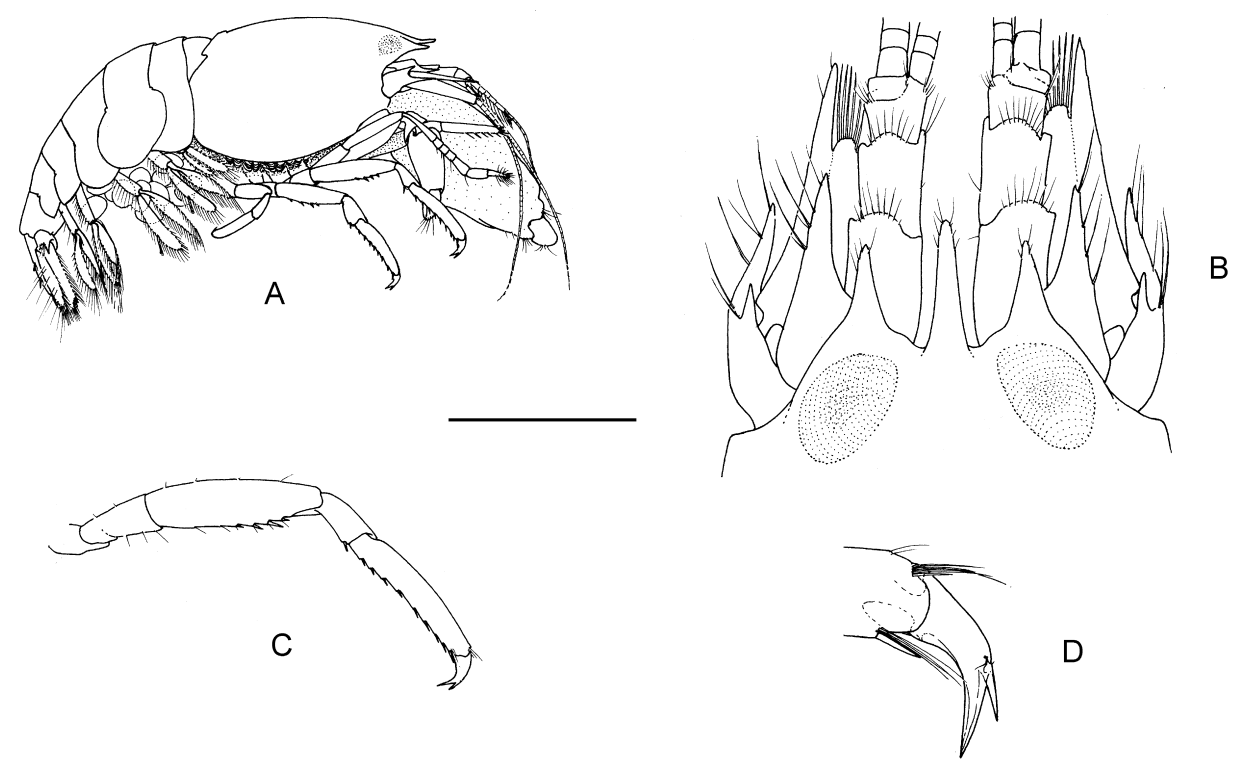

Fig. 6. Synalpheus aff. neomeris (De Man, 1897). Ovigerous female, pocl. $5.1 \mathrm{~mm}$, RMNH D 51615. A, lateral aspect; B, anterior appendages, dorsal aspect; C, left third pereiopod; D, do., dactylus. Scale: $\mathrm{A}=4 \mathrm{~mm} ; \mathrm{B}=1 \mathrm{~mm} ; \mathrm{C}=2 \mathrm{~mm} ; \mathrm{D}=0.15 \mathrm{~mm}$. 
Chela of minor first pereiopod not spatulate, fingers slightly more than half of palm length; merus with dorsodistal margin with acute tooth. Major chela with acute tooth above dactylar articulation; merus with dorsodistal acute tooth.

Third pereiopod with 4-5 meral spines; one distoventral spine on carpus; propodus bowed with row of c. 8 ventral spines, increasing in number with body size, and two ventrodistal spines; dactylus biunguiculate, moderately slender, strongly hooked; unguis half as long as accessory tooth; accessory tooth three times as broad as proximal width of unguis.

Telson with stout dorsal spines at about 0.4 and 0.6 of its length; distolateral angles not projecting, acute.

Remarks. - Specimens of this species have been recorded from both Alcyonaria and Porifera. The specimens found on Alcyonaria might belong to a different species than those found in Porifera. The unguis of the Alcyonaria-associated specimens is about a third of the length of the accessory tooth, while it is about half the length in the Porifera-associated specimens. The accessory tooth is usually somewhat upturned in the Alcyonaria-associated specimens while straigth in the Porifera-associated specimens. P1 minor has the fingers slender and about as long as the palm in the Alcyonaria-associated specimens (see De Man, 1911, pl. 6 figs. 24, 25), while the fingers are more robust and distinctly shorter than the palm in the Porifera-associated specimens. Specimens associated with Porifera have the third pereiopod with about 4 meral spines versus only one in the Alcyonaria-associated specimens. Spines on the telson are large, situated at about 0.4 and 0.6 of the telson length in Porifera-associated specimens, smaller and at about 0.5 and 0.7 of the telson length in Alcyonaria-associated specimens. The lectotype and paralectotypes (D.M. Banner \& A.H. Banner, 1975, fig. 22i, j) have the unguis a third of the length of the accessory tooth and are most likely collected from alcyonarians.

\section{DISCUSSION}

Colonies of Synalpheus species as described here for Synalpheus fossor, S. neptunus neptunus, $S$. hastilicrassus, and $S$. aff. neomeris, are unusual among alpheids in their apparent tolerance of conspecifics. The unusual colony organization of these sponge-dwelling alpheids is similar to those found in various social insects. In $S$. fossor and $S$. aff. neomeris, a few large male and ovigerous female specimens are present in each colony together with many small (probably juvenile) specimens. The cases where more than one ovigerous female was present in a sponge host could be explained by the simultaneous presence of multiple breeding pairs. In a specimen of the host sponges Dysidea arenaria collected at the island of Liukan at the southernmost tip of Sulawesi, colonies of both $S$. fossor and S. aff. neomeris 
were encountered, indicating that these species also tolerate colonies of congeneric species.

S. neptunus neptunus has a colony structure that is comparable to that of the Caribbean eusocial species, $S$. regalis and $S$. filidigitus. This suggests that $S$. neptunus neptunus is indeed a eusocial species, as suggested by Duffy \& Macdonald (1999: 290). One ovigerous female or "queen" was observed in one specimen of Coscinoderma aff. matthewsi; this is the first record of a female $S$. neptunus neptunus. No females were observed in the other five colonies of this S. neptunus neptunus. 'Queen-less' colonies of S. neptunus neptunus have been recorded before by Banner \& Banner (1975), and for S. filidigitus by Duffy \& Macdonald (1999). Duffy \& Macdonald (1999) suggested that this absence might be explained by escape of the female during collection. In the present study, the sponge hosts were collected by covering the complete sponge with a sealed plastic bag, and it is therefore unlikely that a shrimp could have escaped and was missed during dissection. Thus, the absence of an ovigerous female remains unexplained. The observation of abdominal bopyrids only occurring in small, non-ovigerous females and lateral thoracic bopyrids only in males, may indicate some causal link. Possibly, males infected by abdominal bopyrids change their secondary sexual characteristics from male to female, like the softening of the strongly calcified pleura of the abdomen, the loss of the ventroposterior tooth on these pleura, and the elongation of the endopod of the first pleopod.

The within-colony morphological variation found in the development of the male rostrum in S. neptunus neptunus might indicate a highly developed social structure, where polymorphism could be an expression of an underlying genetic structure, and where behavioural diversification (e.g., labour division) is expected. Since it is often suggested that the Crustacea are the marine sister taxon of the terrestrial Arthropoda, the morphological variation between the three types of specimens found in S. neptunus neptunus colonies, can possibly be explained by the adaptive caste structure as found in social insects (Oster \& Wilson, 1978). The colony of S. neptunus neptunus is divided into an extremely large queen, and two distinct types of workers. This colony structure is comparable to the division in queen, minor workers, and major workers (soldiers) as seen in insects. Assessing the significance of within-colony morphological variation in Synalpheus colonies will contribute to our understanding of social organizations.

\section{ACKNOWLEDGEMENTS}

The research of NJDV was funded by the Netherlands Foundation for the Advancement of Tropical Research (NWO-WOTRO, grant W84-474). The fieldwork of KD was financed by the Jan-Joost ter Pelwijk Fonds, Schure-Beijerinck-Popping Fonds (SBP/JK/2002-09), Groninger Universiteits Fonds, Marco Polo Fonds, and 
Fonds Dr. Christine Buisman (B 0202). The Indonesian Institute for Science (LIPI) supported the logistics in Indonesia. Prof. Alfian Noor and Dr. Willem Moka (Hasanuddin University, Makassar) kindly provided access to their laboratory and supported in many other ways. We are much indebted to Arni Janssen, who collected some of the samples in the Spermonde Archipelago. Dr. Rob van Soest (Amsterdam) is thanked for checking all generic names of the sponges.

\section{REFERENCES}

Andersson, M., 1984. The evolution of eusociality. Annual Review of Ecology and Systematics, 15: $165-189$.

BAnner, A. H. \& D. M. BAnner, 1966. The alpheid shrimp of Thailand: the alpheid shrimp of the Gulf of Thailand and adjacent waters. The Siam Society Monograph Series, 3: i-vi, 1-168, figs. 1-62.

Banner, D. M. \& A. H. BAnner, 1975. The alpheid shrimp of Australia. Part 2: the genus Synalpheus. Records of the Australian Museum, 29: 267-389.

BRUCE, A. J., 1976. Shrimps and prawns of coral reefs, with special reference to commensalism. In: O. A. Jones \& R. EndEAn, Biology and geology of coral reefs, 3: Biology (2): 37-94. (Academic Press, New York).

COUtiÈRe, H., 1898. Observations sur quelques animaux des récifs madréporiques de Djibouti. Bulletin du Muséum d'Histoire Naturelle, Paris, 4 (6): 274-276.

- - 1905. Les Alpheidae. In: J. STANLEY GARDINER, The fauna and geography of the Maldive and Laccadive Archipelagoes, 2(4): 852-921, pls. 70-87.

— - 1908. Sur quelques nouvelles espèces d'Alpheidae. Bulletin de la Société Philomatique de Paris, (9) 10: 191-216.

_ _, 1921. Les espèces d'Alpheidae rapportées de l'océan Indien par M. J. Stanley Gardiner. The Percy Sladen Trust Expedition to the Indian Ocean, under the leadership of Mr. J. Stanley Gardiner, M.A., 6 (10). Transactions of the Linnean Society of London, (Zoology) (2) 17 (4): 413-428, pls. 60-64.

DANA, J. D., 1852a. Conspectus crustaceorum. Conspectus of the Crustacea of the exploring expedition under Capt. Wilkes, U.S.N. Proceedings of the Academy of Natural Sciences of Philadelphia, 1852: 10-28.

- —, 1852b. Crustacea. Part I. United States Exploring expedition during the years 1838, 1839, 1840, 1841, 1842, under the Command of Charles Wilkes, U. S. N., 13: i-viii, 1-1620. (Philadelphia).

DUFFY, J. E., 1992. Host use patterns and demography in a guild of tropical sponge-dwelling shrimp. Marine Ecology Progress Series, 90: 127-138.

— —, 1996a. Eusociality in a coral-reef shrimp. Nature, London, 381: 512-514.

— _ 1996b. Synalpheus regalis, new species, a sponge-dwelling shrimp from the Belize Barrier Reef, with comments on host specifity in Synalpheus. Journal of Crustacean Biology, 16 (3): 564-573.

— —, 2002. Eusociality in sponge-dwelling shrimp. In: T. KIKUCHI, Genes, behaviour, and evolution in social insects: 1-38. (University of Hokkaido Press, Sapporo).

Duffy, J. E. \& K. S. MacdonAld, 1999. Colony structure of the social snapping shrimp Synalpheus filidigitus in Belize. Journal of Crustacean Biology, 19 (2): 283-292.

DufFy, J. E., C. L. MORRISON \& K. S. MACDONDALD, 2002. Colony defense and behavioral differentiation in the eusocial shrimp Synalpheus regalis. Behavioral Ecology and Sociobiology, 51: 488-495. 
DUfFy, J. E., C. L. MORRISON \& R. RiOs, 2000. Multiple origins of eusociality among spongedwelling shrimps (Synalpheus). Evolution, 54 (2): 503-516.

FELDER, D. L., 1982. Reproduction of the snapping shrimps Synalpheus fitzmuelleri and S. apioceros (Crustacea: Decapoda: Alpheidae) on a sublittoral reef off Texas. Journal of Crustacean Biology, 2: 535-543.

Holthuis, L. B., 1991. FAO species catalogue. Marine lobsters of the world. An annotated and illustrated catalogue of species of interest to fisheries known to date. FAO Fisheries Synopsis, 13 (125): i-vii, 1-292, figs. 1-459.

— -1993 . The recent genera of the caridean and stenopodidean shrimps (Crustacea, Decapoda), with an appendix on the order Amphionidacea: 1-328, figs. 1-312. (Nationaal Natuurhistorisch Museum, Leiden).

Hooper, J. N. \& R. W. M. van Soest, 2002. Systema Porifera: a guide to the classification of sponges: 1-1810. (Kluwer Academic/Plenum, Amsterdam).

JARVIS, J. U. M., 1981. Eusociality in a mammal: cooperative breeding in naked mole rat. Science, New York, 212: 571-573.

Johnson, M. W., F. A. Everest \& R. W. Young, 1947. The role of snapping shrimp (Crangon and Synalpheus) in the production of underwater noise in the sea. Biological Bulletin, Woods Hole, 93 (2): 122-138.

MAN, J. G. DE, 1897. Bericht über die von Herrn Schiffskapitän Storm zu Atjeh, an den westlichen Küsten von Malakka, Borneo und Celebes, sowie in der Javasee gesammelten Dekapoden und Stomatopoden. Sechster Teil. Zoologische Jahrbücher, (Abteilung für Systematik, Geographie und Biologie der Tiere) 9: 725-790, pls. 12-14.

— - 1909. Diagnoses of new species of macrurous decapod Crustacea from the "SibogaExpedition”. IV. Tijdschrift der Nederlandsche Dierkundige Vereeniging, (2) 11 (2): 99-125.

— — 1911. The Decapoda of the Siboga-Expedition, II: family Alpheidae. Siboga-Expedition Monographs, 39a $\mathbf{1}^{\mathbf{1}}$ (2): 133-465.

— - 1920. Diagnoses of some new species of Penaeidae and Alpheidae with remarks on two known species of the genus Penaeopsis A. M.-Edw. from the Indian Archipelago. Zoologische Mededeelingen, Leiden, 5 (3): 103-109.

_ — 1922. The Decapoda of the Siboga Expedition, Part V: on a collection of macrurous decapod Crustacea of the Siboga Expedition, chiefly Penaeidae and Alpheidae. Siboga Expeditie Monograph, 39a $\mathbf{a}^{4}$ (5): 1-51, pls. 1-4.

Oster, G. F. \& E. O. Wilson, 1978. Caste and ecology in social insects: 1-352. (Princeton University Press, Princeton, New Jersey).

PAUlson, O., 1875. Podophthalmata i Edriophthalmata. In: Issledovaniya Rakoobraznykh Krasnogo morya s zametkami otnositel'no rakoobraznykh drugikh morei, 1: i-xiv, 1-144, pls. 1-21. (S.V. Kul'zhenko, Kiev). [In Russian.] [English translation: PoR, F. D., 1961. Studies on Crustacea of the Red Sea: 1-164. (National Science Foundation, Washington, D.C. and Israel Program for Scientific Translations, Jerusalem).]

Pearse, A. S., 1950. Notes on the inhabitants of certain sponges at Bimini. Ecology, 31 (1): 149151.

VandenSpiegel, D., I. Eeckhaut \& M. JangouX, 1998. Host selection by Synalpheus stimpsoni (De Man), an ectosymbiotic shrimp of comatulid crinoids, inferred by a field survey and laboratory experiments. Journal of Experimental Marine Biology and Ecology, 225 (2): 185-196.

Voogd, N. J. De, R. W. M. van Soest \& B. W. Hoeksema, 1999. Cross-shelf distribution of southwest Sulawesi reef sponges. Memoirs of the Queensland Museum, 44: 147-154.

First received 23 January 2006.

Final version accepted 29 March 2006. 